\title{
Short term results of percutaneous transluminal coronary angioplasty with the monorail technique: experience in the first 1000 patients
}

Pim J de Feyter, Patrick W Serruys, Marcel van den Brand, Harry Suryapranata, Kevin Beatt

\begin{abstract}
The monorail technique allows monitoring of all steps of the coronary angioplasty procedure by high quality coronary angiography; easy, rapid, and safe recrossing and redilatation of the lesion if necessary; and stepwise dilatation of a stenosis with sequential increase of size of balloons. Transstenotic pressure differences cannot, however, be measured through the narrow shaft of the standard monorail balloon catheter.

The monorail technique was used in 1014 patients ( 820 men, 194 women; mean age 57.8 years (range 24 to 84 )). The indication for coronary angioplasty was stable angina in $52 \%$, unstable angina in $40 \%$, and acute myocardial infarction in $8 \%$. Single vessel coronary angioplasty was attempted in $78 \%$, multilesion coronary angioplasty in $11 \%$, and multivessel coronary angioplasty in $11 \%$. Angiographic success (reduction of stenosis to less than $50 \%$ of the luminal diameter) of all attempted lesions was achieved in $93 \%$. The technique was clinically successful-that is, angiographic success of all attempted lesions, no occurrence of a major complication (death, myocardial infarction, acute bypass surgery), and improvement of symptoms-in $92 \%$ and partially successful in $1 \cdot 3 \%$. The clinical success rates were similar for stable angina (91\%) and unstable angina $(94 \%)$, but were somewhat lower for acute myocardial infarction $(88 \%)$. Failure without major complication occurred in $3.4 \%$ of the patients. Failure with a major complication occurred in $3.3 \%$ (death $0.3 \%$, myocardial infarction $2 \cdot 4 \%$, and acute bypass surgery $2 \cdot 3 \%$ ). The total major complication rate was higher in unstable angina $(4 \cdot 2 \%)$ than in stable angina (3.0\%).
\end{abstract}

These results indicate that the monorail technique can be applied safely and effectively for coronary angioplasty of patients with stable angina, unstable angina, and acute myocardial infarction.

Significant advances have been made in the technology of guiding catheters, dilatation catheters, and guide wires since the first introduction of percutaneous transluminal coronary angioplasty in 1977 by Andreas Gruentzig. ${ }^{1}$ Simpson et al further developed the balloon dilatation equipment by introducing a steerable coaxial guide wire. ${ }^{2}$ Subsequent improvements were the miniaturisation of the balloon catheters (low profile balloons) to facilitate the crossing of very severe and distal stenoses. A more recent improvement is the combination of the long (exchange) guide wire technique ${ }^{34}$ and a newly developed balloon catheter to form one new dilatation system: the monorail system, for which a change in dilatation technique is needed. ${ }^{5}$ This monorail technique allows all steps of the coronary angioplasty procedure to be monitored on high quality angiograms: easy, rapid, and safe recrossing and redilatation of the stenosis if necessary; stepwise dilatation of a stenosis with sequential use of bigger balloons.

We describe our experience and the short term results of coronary angioplasty with the monorail technique in the first 1000 patients.

\section{Patients and methods}

\section{PATIENTS}

From June 1986 to December 19881472 patients underwent coronary angioplasty at the Thoraxcenter in Rotterdam. We excluded (a) patients in whom a stent was implanted $(\mathrm{n}=13),(b)$ patients who were selected for the assessment of a newly developed catheter balloon system ( $n=46)$; and (c) patients with bifurcation lesions in whom the (partial) kissing balloon technique was used $(\mathbf{n}=15)$. Table 1 shows the baseline clinical characteristics of the remaining 1398 patients. These patients were classified into three groups: 1014 patients were selected for coronary angioplasty with the monorail technique, 325 patients were selected for coronary angioplasty with the long guide wire technique, and 59 patients were selected for coronary angioplasty with other balloon catheters (microbore, 54 patients; balloon on wire, five patients).

\section{ANGIOGRAPHY}

Coronary artery lesions were classified as occurring in the left anterior descending 
Table 1 Baseline clinical characteristics of patients according to type of coronary angioplasty attempted

\begin{tabular}{|c|c|c|c|}
\hline & $\begin{array}{l}\text { Monorail } \\
\text { technique } \\
(n=1014) \\
\%(n) \\
\end{array}$ & $\begin{array}{l}\text { Long guide } \\
\text { wire } \\
\text { technique } \\
(n=325) \\
\%(n)\end{array}$ & $\begin{array}{l}\text { Other } \\
\text { technique } \\
(n=59) \\
\%(n)\end{array}$ \\
\hline $\begin{array}{l}\text { Mean age (range) }(\mathrm{yr}) \\
>70 \text { yr } \\
\text { Females } \\
\text { Old MI } \\
\text { Previous CABG } \\
\text { EF }<45 \%(\%)\end{array}$ & $\begin{array}{l}58(24-85) \\
11(108) \\
19(194) \\
15(147) \\
10(97) \\
5(47)\end{array}$ & $\begin{array}{l}57(32-82) \\
12(39) \\
16(53) \\
18(57) \\
14(47) \\
5(16)\end{array}$ & $\begin{array}{l}56(35-78) \\
15(9) \\
22(13) \\
32(19) \\
14(8) \\
7(4)\end{array}$ \\
\hline $\begin{array}{l}\text { Multivessel disease: } \\
2 \text { vessel } \\
3 \text { vessel } \\
\text { Total occlusion }\end{array}$ & $\begin{array}{c}19(193) \\
8(85) \\
7(75)\end{array}$ & $\begin{array}{l}23(74) \\
12(38) \\
14(47)\end{array}$ & $\begin{array}{c}25(15) \\
7(4) \\
27(16)\end{array}$ \\
\hline $\begin{array}{l}\text { Stable angina } \\
\text { Unstable angina } \\
\text { Acute MI }\end{array}$ & $\begin{array}{c}52(523) \\
40(407) \\
8(84)\end{array}$ & $\begin{array}{l}70(227) \\
26(85) \\
4(13)\end{array}$ & $\begin{array}{c}80(47) \\
20(12) \\
0(0)\end{array}$ \\
\hline $\begin{array}{l}\text { Attempt per vessel: } \\
\text { LAD } \\
\text { RCA } \\
\text { CX } \\
\text { Bypass graft } \\
\text { Left main stem }\end{array}$ & $\begin{array}{c}51(578) \\
26(291) \\
20(221) \\
3(36) \\
1(5)\end{array}$ & $\begin{array}{c}43(159) \\
26(96) \\
25(92) \\
5(17) \\
1(2)\end{array}$ & $\begin{array}{l}43(32) \\
33(26) \\
23(18) \\
1(1) \\
0(0)\end{array}$ \\
\hline $\begin{array}{l}\text { Attempts per patient: } \\
\text { Single vessel } \\
\text { Multilesion } \\
\text { Multivessel }\end{array}$ & $\begin{array}{l}78(791) \\
11(114) \\
11(109)\end{array}$ & $\begin{array}{l}75(244) \\
11(36) \\
14(45)\end{array}$ & $\begin{array}{l}66(39) \\
20(12) \\
14(8)\end{array}$ \\
\hline
\end{tabular}

^Attempted coronary angioplasty with other standard

dilatation technique and other balloons. MI, myocardial infarction; CABG, coronary artery bypass artery; RCA, right coronary artery; $\mathbf{C X}$, circumflex coronary artery, $n=$ number of patients.

artery, left circumflex artery, and right coronary artery, whether or not they occurred within the artery itself or in a side branch of that artery. There was a separate category for lesions of bypass grafts or of the left main stem. Coronary stenosis was expressed as a percentage of the luminal diameter and a lesion of $>50 \%$ was regarded as haemodynamically important. Multivessel disease was defined as a luminal arterial diameter narrowing of more than $50 \%$ in at least two major coronary arteries. A vessel was considered to be totally occluded when no anterograde flow of dye was visible at angiography immediately before the attempted coronary angioplasty. The ejection fraction was calculated from the left ventriculogram in the $30^{\circ}$ right anterior oblique projection.

\section{HISTORY}

Unstable angina was defined as chest pain at rest associated with documented changes in the ST segment or $T$ wave and no obvious signs of myocardial cell necrosis (an increase in cardiac enzymes of less than twice normal or no development of abnormal $Q$ waves). Patients were considered for immediate coronary angioplasty if they had symptoms of acute myocardial infarction (severe, prolonged chest pain not relieved by glyceryl trinitrate and ST segment elevation of at least $1 \mathrm{~mm}$ in at least two contiguous leads) for less than 6 hours after the onset of symptoms.
CORONARY ANGIOPLASTY PROCEDURE

Intravenous heparin (100 mg) and aspirin (250 $\mathrm{mg}$ ) were given at the start of the procedure. The electrocardiogram and blood pressure were monitored continuously. To prevent coronary spasm intracoronary isosorbide dinitrate (10 to $30 \mu \mathrm{g}$ ) was injected and this was repeated when necessary. The initial pressure of balloon inflation was 2.0 atms, with subsequent inflations of up to 12 atms. The duration of inflation was adjusted for electrocardiographic changes, the drop in blood pressure, or induced pain. The number of balloon inflations varied according to the appearance of the lesion on angiography immediately after dilatation.

Multivessel dilatation was defined as dilatation of one or more lesions in two or more major epicardial coronary arteries. Multilesion dilatation was defined as dilatation of two or more lesions in one major epicardial coronary artery. In patients with stable angina and multivessel angioplasty, dilatation of the most severe narrowing in the vessel supplying the largest amount of jeopardised myocardium (critical stenosis) was always attempted first and, if successful, additional vessel(s) were dilated. Angioplasty of a second or third vessel was not attempted if the attempted dilatation of the critical lesion was unsuccessful or when angiographic success was equivocal or if the result was consistent with a dissection that might progress to total occlusion. When a vessel with high grade disease supplied collaterals to another vessel, the vessel receiving the collateral supply was dilated first to protect collateral flow. When sequential lesions were present in one vessel, the more proximal lesion was dilated first. In patients with unstable angina and multivessel disease only the critical lesion (determined by the electrocardiographic changes and angiographic appearance-that is, the severity and complexity of the lesion, irregular borders, intracoronary thromius) was dilated except in 37 patients who were judged to have more than one severe lesion. These were dilated in the same session. In patients with acute myocardial infarction only the infarct related lesion was dilated.

The success of the procedure was judged by both angiographic and clinical criteria. Angiographic success was defined as a reduction of the luminal diameter stenosis to $<50 \%$. A complete clinical success was defined as angiographic success in all attempted lesions, associated with an improvement of symptoms and without evidence of myocardial infarction or the requirement for coronary artery bypass surgery during hospital stay. An incomplete clinical success was defined as angiographic success with the critical lesion but failure with additional lesion(s), associated with an improvement of symptoms and without evidence of myocardial infarction or need for coronary artery bypass surgery during hospital stay.

A coronary angioplasty was regarded as a failure if $(a)$ the angiographer was unable to reach, cross, or dilate the critical lesion while 


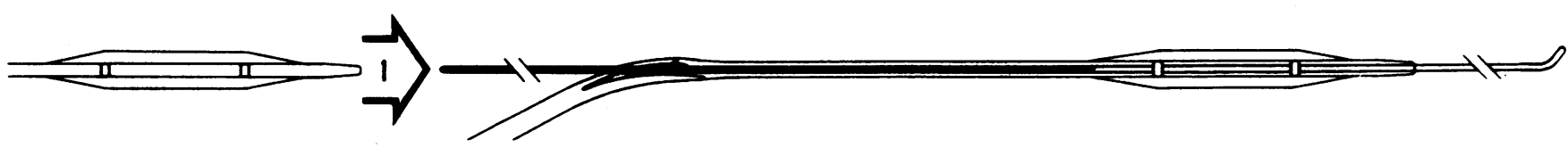

Figure 1 The monorail balloon catheter consists of a lumen running the length of the catheter to inflate and deflate the balloon, and a second lumen (1) limited to the distal end of the catheter that acts as a "monorail" and is occupied by the guide wire.

attempting to perform a coronary angioplasty (failure without complications) or $(b)$ the coronary angioplasty procedure resulted in death, myocardial infarction, or emergency coronary artery bypass surgery. A periinterventional (complication of angioplasty) myocardial infarction was defined as the development of an abnormal $Q$ wave $(\geqslant 0.03 \mathrm{~mm})$ or a typical increase in cardiac enzymes. A perioperative (complication of a bypass operation) myocardial infarction was defined as the development of an abnormal $Q$ wave $(\geqslant 0.03 \mathrm{~mm})$. All procedures were carried out with a surgical team on standby. After the procedure the sheaths were left in place for 6-8 hours and all patients were monitored for 24 hours in an intermediate coronary care unit. All patients were treated with oral nifedipine 60 mg daily for 24-36 hours after coronary angioplasty and were discharged after 1 to 2 days. The patients were treated with aspirin $500 \mathrm{mg}$ daily for 6 months.

\section{MONORAIL TECHNIQUE}

The monorail balloon catheter (BonzelSchneider-Medintag) has a single lumen for balloon inflation and a second lumen limited to the first few centimetres of the distal end of the catheter. This second lumen is occupied by the guide wire that acts as a sliding rail (monorail) for the balloon catheter (fig 1). Table 2 shows the technical details for different types of monorail balloon catheters. In the monorail technique the guide wire alone (SchneiderMedintag $175 \mathrm{~cm}, 0.0012-0.0014$ inch; ACS $175 \mathrm{~cm}, 0.0014$ inch) is initially positioned across the lesion. The small diameter guide wire does not obstruct injection of contrast; thus it allows good delineation of the coronary anatomy and facilitates positioning of the wire across the lesion (fig $2 a$ and $b$ ).

The distal lumen of the balloon catheter is then threaded over the positioned guide wire (the proximal part guide wire is outside the guiding catheter) and the catheter is advanced through the guiding catheter, into the coronary artery tree, and eventually across the lesion (fig 1). Because the position of the guide wire outside the patient is fixed most of the position-

Table 2 Technical details of different monorail dilatation catheters

\begin{tabular}{|c|c|c|c|c|}
\hline & $\begin{array}{l}\text { Balloon } \\
\text { diameter } \\
(\mathrm{mm})\end{array}$ & $\begin{array}{l}\text { Deflated } \\
\text { balloon } \\
\text { profile (inch) }\end{array}$ & $\begin{array}{l}\text { Shaft } \\
\text { diameter }\end{array}$ & $\begin{array}{l}\text { Maximum } \\
\text { recommended } \\
\text { balloon } \\
\text { pressure (atm) }\end{array}$ \\
\hline $\begin{array}{l}\text { Monorail-Bonzel, PVC (super)- } \\
\text { low profile } \\
\text { Monorail Piccolino, PET material } \\
\text { Monorail-Bonzel Snake, with distal } \\
\text { pressure measurement, PVC }\end{array}$ & $\begin{array}{l}2 \cdot 0-4 \cdot 2 \\
1 \cdot 5-4 \cdot 25 \\
3 \cdot 0-4 \cdot 2\end{array}$ & $\begin{array}{l}0.043-0.061 \\
0.028-0.040 \\
0.058-0.063\end{array}$ & $\begin{array}{l}3 F \\
3 F \\
3 \cdot 6 F\end{array}$ & $\begin{array}{l}8-10 \\
8-12 \\
8\end{array}$ \\
\hline
\end{tabular}

All three catheters are of the Schneider-Shiley type.

PCV, polyvinylchloride; PET, polyethylene. ing and withdrawing of the balloon is performed without the need for fluoroscopic control and to and fro motion of the wire in the distal coronary vessel is prevented. The reduced shaft diameter of the balloon catheter means that the injection of contrast when the balloon is in the guiding catheter is not obstructed and this improves the delineation of the coronary anatomy (fig $2 \mathrm{c}$ and 3 ).

After the final dilatation of the lesion the balloon catheter is completely withdrawn outside the guiding catheter while the guide wire remains in the distal vessel. The result of dilatation can again be evaluated under high quality angiographic control and, when necessary, the lesion can be easily recrossed and redilated (fig $2 \mathrm{~d}$ ).

OTHER CORONARY ANGIOPLASTY TECHNIQUES In the remaining patients in whom the monorail technique was not used, coronary angioplasty was performed by standard techniques with either fixed tip or steerable catheter systems or by the long guide wire technique. ${ }^{3}$

\section{CLASSIFICATION OF PATIENTS \\ Monorail group}

Patients were classified as being in the monorail group if the monorail technique was selected as the first choice of catheter balloon system to be used. The patients always remained in the monorail group if, after failure with the monorail technique, an attempt with another balloon catheter system was successful or unsuccessful.

\section{Long guide wire group and other technique group} Patients were classified as being in the long guide wire group or other technique group if either technique was selected as the first approach. The patients remained in this group even after crossover to another technique.

\section{Results}

Most of the baseline clinical characteristics were similar in the three groups (table 1). However, attempted coronary angioplasty of a total occluded lesion and multilesion dilatation were more common in the long guide wire and the other technique groups.

Table 3 shows the short term results of coronary angioplasty with the different techniques. The overall clinical and angiographic success rate was lower in the groups classified as long guide wire technique and in particular in those classified as the other technique group but this may have been because more total occlusions were attempted. The differences in outcome therefore are a reflection of patient selection and do not indicate that one technique was better than the other.

Table 4 shows the results of attempts with 
(a)

(c)

(e)

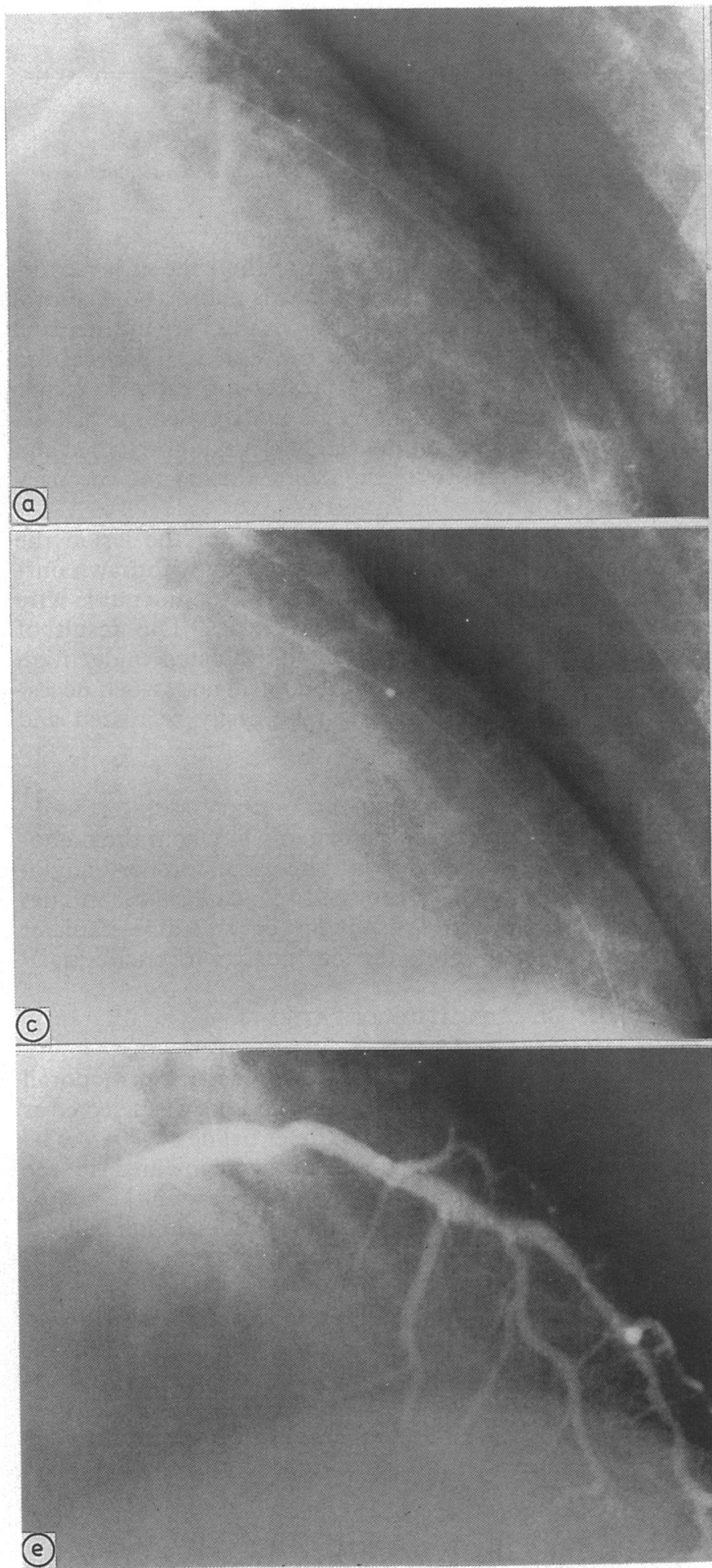

Figure 2 (a) Guide wire alone positioned distal in the left anterior descending artery. (b) Coronary anatomy is well displayed with the guide wire positioned in the artery. (c) Guide wire and deflated balloon positioned at the lesion. (d) Satisfactory display of coronary anatomy with deflated balloon crossing the stenosis. (e) High quality angiogram obtained after withdrawal of balloon catheter, with guide wire

remaining in the distal vessel.

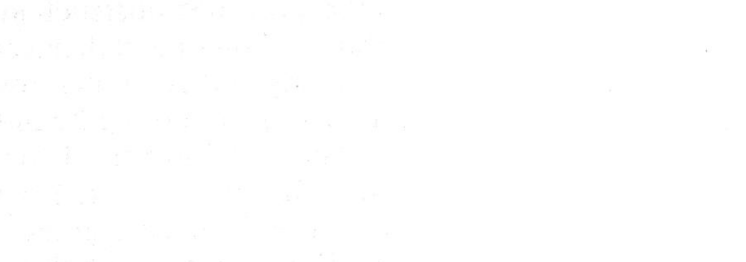

Figure 3 Comparison of space available within $8 F$ guiding catheter when a conventional dilatation catheter $\left(1.1 \mathrm{~mm}^{2}\right)$ or a monorail balloon catheter $\left(2 \mathrm{~mm}^{2}\right)$ is used.
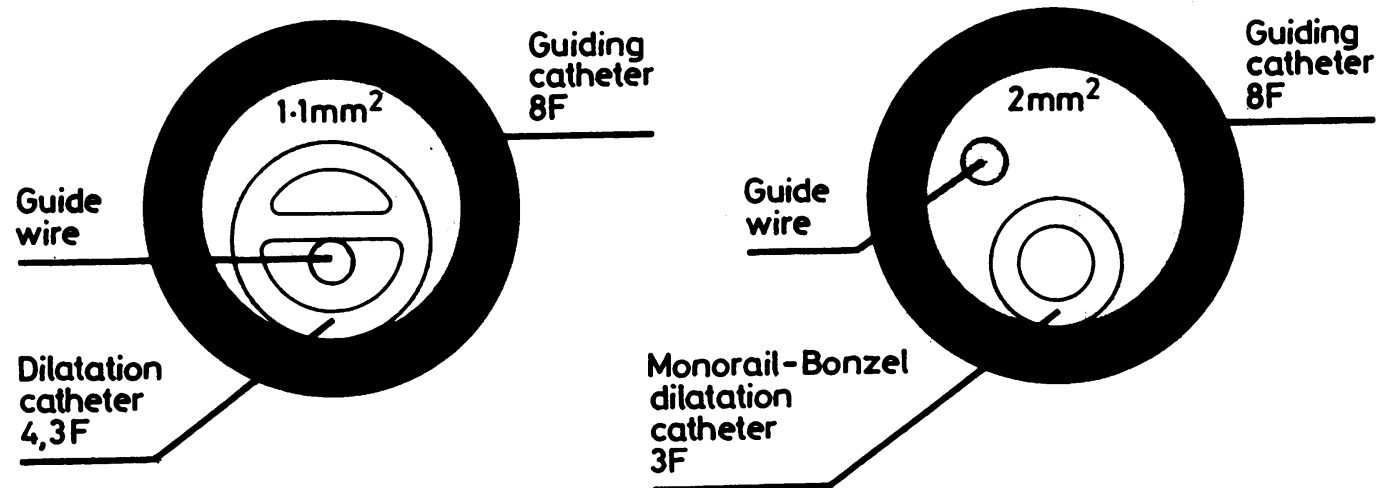

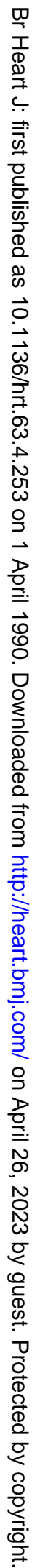
3F 
Table 3 Short term results of coronary angioplasty with the monorail technique, the long guide wire technique, and other technique

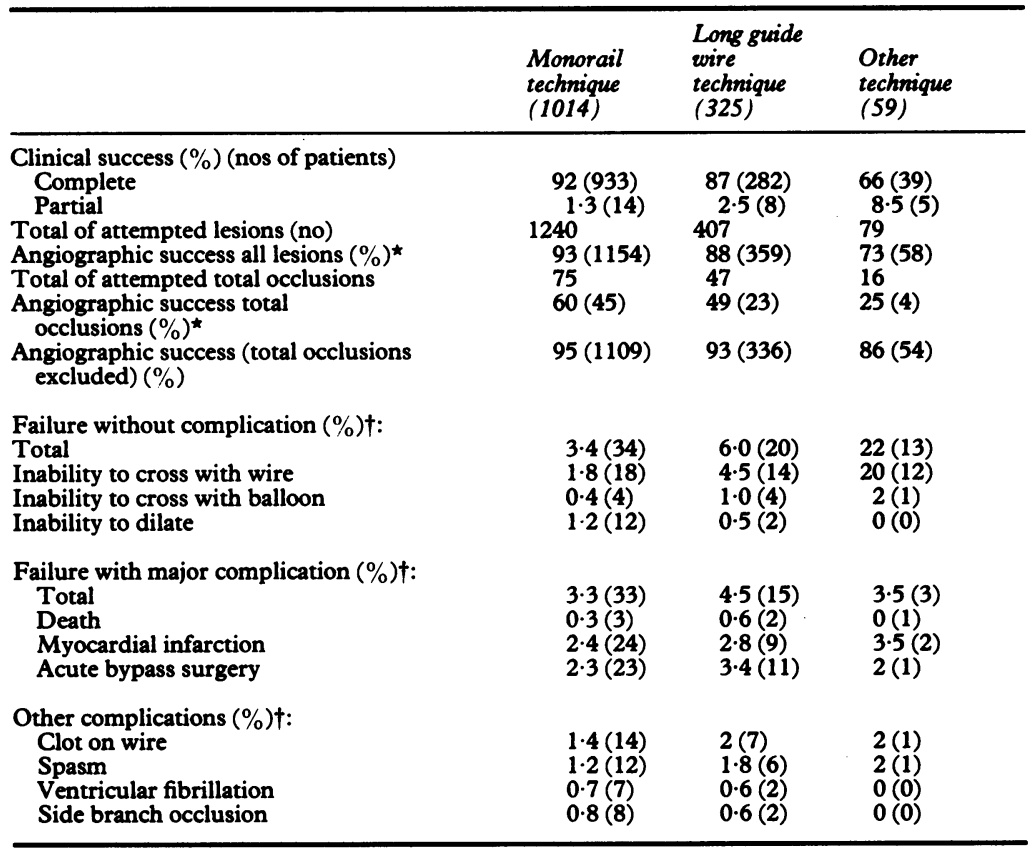

*Number of lesions is given in parentheses.

† Number of patients is given in parentheses.

another technique or balloon catheter after initial failure with the monorail technique. Tables 5, 6, and 7 show the short term results of percutaneous transluminal coronary angioplasty with use of the monorail technique in patients with stable angina, unstable angina,

Table 4 Short term results of attempts with another balloon dilatation catheter after initial failure with the monorail technique

\begin{tabular}{llll}
\hline \multirow{2}{*}{$\begin{array}{l}\text { Attempted } \\
\text { lesions }\end{array}$} & \multicolumn{3}{l}{ Attempt with other balloon catheter } \\
\cline { 2 - 4 } & Total $(n)$ & Success $(n)$ & Failure $(n)$ \\
\hline Single lesion & 5 & $1(0)$ & $4(2)$ \\
Multilesion/multivessel: & 3 & $3(1)$ & $0(0)$ \\
Culprit lesion & 3 & $7(2)$ & $1(1)$ \\
Additional lesion(s) & 8 & & \\
\hline
\end{tabular}

Numbers in parentheses are patients with total occlusion. and acute myocardial infarction. These results indicate that the monorail technique can be used as an elective (table 5), semi-elective (table 6), or emergency procedure (table 7) and indicate that with the use of the monorail technique stenoses in all three major coronary arteries and venous bypass grafts are equally accessible and that the primary success rates and reasons for failure in these vessels are comparable. Table 8 shows the short term results of attempted coronary angioplasty with the monorail technique for totally occluded lesions. The higher success rate in patients with unstable angina reflects the shorter interval between total occlusion and attempted coronary angioplasty.

\section{Discussion}

Primary success of percutaneous transluminal coronary angioplasty depends on many factors. The most important are patient selection, lesion location, operator experience, dilatation equipment, and adequate radiographic equipment. ${ }^{6-9}$ Undoubtedly improvements in balloon catheter designs and dilatation techniques have increased success rates. We describe the initial results obtained with the use of the monorail technique and do not compare the success rates or complication rates with the monorail technique with other techniques or other balloon catheter systems. Although such a study is desirable, it would require a randomised design and, because of the expected small differences in outcome, it would require the recruitment of a large study group from more than one centre with many investigators. Furthermore, such a study would take several years and continuing refinements and improvements of balloon catheters or the introduction of new techniques (laser, atherectomy, abrasive catheters, ultrasound energy) would make the comparison unreliable. We describe our experience with the monorail technique used as a primary routine in one interventional cardiology centre in which about

Table 5 Short term results of percutaneous transluminal coronary angioplasty by the monorail technique in patients with stable angina

\begin{tabular}{|c|c|c|c|c|c|c|c|c|c|c|}
\hline & \multirow[b]{3}{*}{$\begin{array}{l}\text { Total } \\
(\boldsymbol{n})\end{array}$} & \multirow{2}{*}{\multicolumn{3}{|c|}{ Clinical success }} & \multicolumn{6}{|l|}{ Failure $^{\star}$} \\
\hline & & & & & \multicolumn{2}{|c|}{ No complications } & \multicolumn{4}{|c|}{ With complications } \\
\hline & & $\begin{array}{l}\text { success } \\
\text { \% (lesions) }\end{array}$ & $\begin{array}{l}\text { Complete } \\
\%(n)\end{array}$ & $\begin{array}{l}\text { Partial } \\
\%(n)\end{array}$ & $\begin{array}{l}U C \\
\%(n)\end{array}$ & $\begin{array}{l}U B \\
\%(n)\end{array}$ & $\begin{array}{l}\text { Total } \\
\%(n)\end{array}$ & $\begin{array}{l}\text { Death } \\
(n)\end{array}$ & $\begin{array}{c}M I \\
(n)\end{array}$ & $\underset{(n)}{C A B G}$ \\
\hline $\begin{array}{l}\text { Single vessel attempt: } \\
\text { LAD } \\
\text { RCA } \\
\text { CX } \\
\text { Bypass graft } \\
\text { Left mainstem }\end{array}$ & $\begin{array}{r}202 \\
99 \\
70 \\
9 \\
4\end{array}$ & $\begin{array}{l}92(186) \\
87(86) \\
94(66) \\
89(8) \\
100(4)\end{array}$ & $\begin{array}{l}92(186) \\
87(86) \\
94(66) \\
89(8) \\
100(4)\end{array}$ & $\begin{array}{l}z \\
z \\
z\end{array}$ & $\begin{array}{c}2 \cdot 5(5) \\
6(6) \\
3(2) \\
11(1) \\
0\end{array}$ & $\begin{array}{l}1.5(3) \\
2(2) \\
1.5(1) \\
0 \\
0\end{array}$ & $\begin{array}{l}4.0(8) \\
5(5) \\
1.5(1) \\
0 \\
0\end{array}$ & $\begin{array}{l}0 \\
0 \\
0 \\
0 \\
0\end{array}$ & $\begin{array}{l}4 \\
3 \\
1 \\
0 \\
0\end{array}$ & $\begin{array}{l}8 \\
2 \\
1 \\
0 \\
0\end{array}$ \\
\hline $\begin{array}{l}\text { Multilesion attempt: } \\
\text { LAD } \\
\text { RCA } \\
\text { CX }\end{array}$ & $\begin{array}{r}41 \\
22 \\
4\end{array}$ & $\begin{array}{l}96(80) \\
98(42) \\
88(7)\end{array}$ & $\begin{array}{l}95(39) \\
95(21) \\
75(3)\end{array}$ & $\begin{array}{l}2 \cdot 5(1) \\
5(1) \\
25(1)\end{array}$ & $\begin{array}{l}0 \\
0 \\
0\end{array}$ & $\begin{array}{l}\mathbf{0} \\
\mathbf{0} \\
\mathbf{0}\end{array}$ & $\begin{array}{l}2.5(1) \\
0 \\
0\end{array}$ & $\begin{array}{l}0 \\
0 \\
0\end{array}$ & $\begin{array}{l}1 \\
0 \\
0\end{array}$ & $\begin{array}{l}1 \\
0 \\
0\end{array}$ \\
\hline $\begin{array}{l}\text { Multivéssel attempt: } \\
\text { LAD/CX } \\
\text { LAD/RCA } \\
\text { RCA/CX } \\
\text { Bypass graft/other } \\
\text { LAD/CX/RCA }\end{array}$ & $\begin{array}{r}31 \\
23 \\
12 \\
4 \\
\quad 2\end{array}$ & $\begin{array}{c}97(58) \\
93(43) \\
75(18) \\
100(8) \\
83(5)\end{array}$ & $\begin{array}{l}94(29) \\
91(21) \\
58(7) \\
100(4) \\
50(1)\end{array}$ & $\begin{array}{r}6(2) \\
4(1) \\
33(4) \\
0(0) \\
50(1)\end{array}$ & $\begin{array}{l}0 \\
0 \\
8(1) \\
0 \\
0\end{array}$ & $\begin{array}{l}0 \\
0 \\
0 \\
0 \\
0\end{array}$ & $\begin{array}{l}0 \\
4(1) \\
0 \\
0 \\
0\end{array}$ & $\begin{array}{l}0 \\
0 \\
0 \\
0 \\
0\end{array}$ & $\begin{array}{l}0 \\
1 \\
0 \\
0 \\
0\end{array}$ & $\begin{array}{l}0 \\
0 \\
0\end{array}$ \\
\hline All attempts & 523 & $92(611)$ & $91(475)$ & $2(11)$ & $2 \cdot 8(15)$ & $1 \cdot 2(6)$ & $3.0(16)$ & 0 & 10 & 12 \\
\hline
\end{tabular}

*UC, uncrossed wire; UB, unable to cross lesion to dilate with balloon.
MI, myocardial infarction; CABG, coronary artery bypass grafting; LAD, left anterior descending coronary artery; RCA, right coronary artery; $\mathrm{CX}$, circumflex coronary artery. $\mathrm{n}=$ number of patients. 
Table 6 Short term results of percutaneous transluminal coronary angioplasty by the monorail technique in patients with unstable angina

\begin{tabular}{|c|c|c|c|c|c|c|c|c|c|c|}
\hline & \multirow[b]{3}{*}{$\begin{array}{l}\text { Total } \\
(n)\end{array}$} & \multirow{2}{*}{\multicolumn{3}{|c|}{ Clinical success }} & \multicolumn{6}{|c|}{ Failure ${ }^{\star}$} \\
\hline & & & & & \multicolumn{2}{|c|}{ No complications } & \multicolumn{4}{|c|}{ With complications } \\
\hline & & $\begin{array}{l}\text { success } \\
\% \text { (lesions) }\end{array}$ & $\begin{array}{l}\text { Complete } \\
\%(n)\end{array}$ & $\begin{array}{l}\text { Partial } \\
\%(n)\end{array}$ & $\begin{array}{l}U C \\
\%(n)\end{array}$ & $\begin{array}{l}U B \\
\%(n)\end{array}$ & $\begin{array}{l}\text { Total } \\
\%(n)\end{array}$ & $\begin{array}{l}\text { Death } \\
(n)\end{array}$ & $\begin{array}{c}M I \\
(n)\end{array}$ & $\underset{(n)}{C A B G}$ \\
\hline $\begin{array}{l}\text { Single vessel atte } \\
\text { LAD } \\
\text { RCA } \\
\text { CX } \\
\text { Bypass }\end{array}$ & $\begin{array}{r}183 \\
69 \\
62 \\
9\end{array}$ & $\begin{array}{c}94(172) \\
93(64) \\
97(60) \\
100(9)\end{array}$ & $\begin{array}{c}94(172) \\
93(64) \\
97(60) \\
100(9)\end{array}$ & $\begin{array}{l}E \\
z\end{array}$ & $\begin{array}{l}1(2) \\
1 \cdot 5(1) \\
0 \\
0\end{array}$ & $\begin{array}{l}0 \\
0 \\
0 \\
0\end{array}$ & $\begin{array}{l}5(9) \\
6(4) \\
3(2) \\
0(0)\end{array}$ & $\begin{array}{l}2 \\
1 \\
0 \\
0\end{array}$ & $\begin{array}{l}7 \\
3 \\
2 \\
0\end{array}$ & $\begin{array}{l}6 \\
2 \\
2 \\
0\end{array}$ \\
\hline $\begin{array}{l}\text { Multilesion attem } \\
\text { LAD } \\
\text { RCA } \\
\text { CX }\end{array}$ & $\begin{array}{r}26 \\
12 \\
9\end{array}$ & $\begin{array}{r}94(50) \\
100(24) \\
94(17)\end{array}$ & $\begin{array}{c}88(23) \\
100(12) \\
89(8)\end{array}$ & $\frac{4(1)}{11(1)}$ & $\begin{array}{l}0 \\
0 \\
0\end{array}$ & $\begin{array}{l}0 \\
0 \\
0\end{array}$ & $\begin{array}{l}8(2) \\
0(0) \\
0(0)\end{array}$ & $\begin{array}{l}0 \\
0 \\
0\end{array}$ & $\begin{array}{l}2 \\
0 \\
0\end{array}$ & $\begin{array}{l}1 \\
0 \\
0\end{array}$ \\
\hline $\begin{array}{l}\text { Multivessel attem } \\
\text { LAD/CX } \\
\text { LAD/RCA } \\
\text { RCA/CX } \\
\text { L-main/CX }\end{array}$ & $\begin{array}{r}13 \\
12 \\
8 \\
1\end{array}$ & $\begin{array}{l}96(25) \\
100(24) \\
100(16) \\
100(2)\end{array}$ & $\begin{array}{l}92(12) \\
100(12) \\
100(8) \\
100(1)\end{array}$ & $\begin{array}{l}8(1) \\
-\end{array}$ & $\begin{array}{l}0 \\
0 \\
0 \\
0\end{array}$ & $\begin{array}{l}0 \\
0 \\
0 \\
0\end{array}$ & $\begin{array}{l}0 \\
0 \\
0 \\
0\end{array}$ & $\begin{array}{l}0 \\
0 \\
0 \\
0\end{array}$ & $\begin{array}{l}0 \\
0 \\
0 \\
0\end{array}$ & $\begin{array}{l}0 \\
0 \\
0 \\
0\end{array}$ \\
\hline $\begin{array}{l}\text { Bypass/LAD(2) } \\
\text { CX(1) }\end{array}$ & 3 & $100(6)$ & $100(3)$ & - & 0 & 0 & 0 & 0 & 0 & 0 \\
\hline All attempts & 407 & $95(469)$ & $94(384)$ & $0.7(3)$ & $0.7(3)$ & 0 & $4 \cdot 2(17)$ & 3 & 14 & 11 \\
\hline
\end{tabular}

Table 7 Acute results of percutaneous transluminal coronary angioplasty by the monorail technique in patients with acute myocardial infarction $\star$

\begin{tabular}{|c|c|c|c|c|}
\hline & \multirow[b]{2}{*}{$n$} & \multirow{2}{*}{$\begin{array}{l}\text { Clinical } \\
\text { success } \\
(\%)(n)\end{array}$} & \multicolumn{2}{|l|}{ Failure } \\
\hline & & & $\begin{array}{l}U C \\
\%(n)\end{array}$ & $\begin{array}{l}U B \\
\%(n)\end{array}$ \\
\hline $\begin{array}{l}\text { Single vessel: } \\
\text { LAD } \\
\text { RCA } \\
\text { CX } \\
\text { Bypass graft }\end{array}$ & $\begin{array}{r}43 \\
32 \\
8 \\
1\end{array}$ & $\begin{array}{c}93(40) \\
81(26) \\
88(7) \\
100(1)\end{array}$ & $\begin{array}{l}.0 \\
0 \\
0 \\
0\end{array}$ & $\begin{array}{c}7(3) \\
19(6) \\
12(1) \\
0\end{array}$ \\
\hline All attempts & 84 & $88(74)$ & 0 & $12(10)$ \\
\hline
\end{tabular}

*There were no deaths.

See footnote to table 5 for abbreviations.

500 patients per year were treated by angioplasty.

\section{MONORAIL TECHNIQUE}

Nowadays, in elective procedures with low profile or super low profile dilatation catheters the initial success rate should be well over $90 \% \cdot{ }^{10-12}$ None the less, angioplasty patients continue to be at risk of major periprocedural complications. Optimal visualisation and continued access to the distal part of the vessel are useful in preventing, recognising and facilitating the management of these acute complications.

The monorail technique allows (a) optimal visualisation to monitor all the important steps of the coronary angioplasty procedure; $(b)$ safe, rapid, and easy recrossing of the lesion if necessary, and $(c)$ initial crossing of a tight or complex lesion with a small balloon and recrossing of the stenosis with larger balloons. Optimal visualisation is essential for negotiation of the proximal and distal parts of the coronary artery, for crossing of the lesion, and for recognition and management of the complications of the procedure. If dilatation is incomplete or an acute coronary occlusion occurs during angioplasty the monorail technique enhances recognition of these situations and allows easy and safe recrossing with the same or a larger balloon. If this is unsuccessful a monorail coronary perfusion catheter can be introduced and coronary blood perfusion can be performed. The guide wire is withdrawn only after the control angiogram has shown a satisfactory result. In patients with a high risk of abrupt occlusion after an initial successful dilatation the technique permits monitoring of the patient in the catheterisation laboratory with continued access provided by the wire in the distal part of the vessel.

LIMITATIONS OF THE MONORAIL TECHNIQUE

The shaft of the standard monorail balloon catheter is too narrow to allow measurement of the transstenotic pressure difference. Undoubtedly measurement of transstenotic pressure differences by commercial equipment is less accurate than by high-fidelity micro-

Table 8 Short term results of percutaneous transluminal coronary angioplasty by the monorail technique in patients with occlusion of a coronary artery

\begin{tabular}{|c|c|c|c|c|c|c|c|c|c|}
\hline & \multirow[b]{3}{*}{$(n)$} & \multirow{2}{*}{\multicolumn{2}{|c|}{ Clinical success }} & \multicolumn{6}{|l|}{ Failure } \\
\hline & & & & \multicolumn{2}{|c|}{ No complications } & \multicolumn{4}{|c|}{ With complications } \\
\hline & & $\begin{array}{l}\text { Complete } \\
\%(n)\end{array}$ & $\begin{array}{l}\text { Partial } \\
\%(n)\end{array}$ & $\begin{array}{l}U C \\
\%(n)\end{array}$ & $\begin{array}{l}U B \\
\%(n)\end{array}$ & $\begin{array}{l}\text { Total } \\
\%(n)\end{array}$ & $\begin{array}{l}\text { Death } \\
(n)\end{array}$ & $\begin{array}{c}M I \\
(n)\end{array}$ & $\begin{array}{l}C A B G \\
(n)\end{array}$ \\
\hline $\begin{array}{l}\text { Stable angina } \\
\text { Unstable angina }\end{array}$ & $\begin{array}{l}50 \\
25\end{array}$ & $\begin{array}{l}52(26) \\
76(19)\end{array}$ & $\begin{array}{l}8(4) \\
0(0)\end{array}$ & $\begin{array}{l}30(15) \\
12(3)\end{array}$ & $\begin{array}{l}8(4) \\
0(0)\end{array}$ & $\begin{array}{r}2(1) \\
12(3)\end{array}$ & $\begin{array}{l}0 \\
1\end{array}$ & $\begin{array}{l}1 \\
2\end{array}$ & $\begin{array}{l}0 \\
2\end{array}$ \\
\hline
\end{tabular}


manometers. ${ }^{1314}$ None the less, haemodynamic evaluation of the lesion by such methods may help to predict restenosis ${ }^{15}$ and provide immediate additional information to support the angiographic result. Reduction in the diameter of the catheter allows high quality visualisation but precludes measurement of the transstenotic pressure gradient whereas an increase in diameter allows measurement of a pressure gradient but precludes high quality angiography. We believe that high quality visualisation is more helpful than measurement of a transstenotic pressure drop in the assessment of the result immediately after dilatation. The Monorail-Bonzel Snake balloon catheter, however, is designed to measure the drop in pressure gradient (table 2 ).

The poor pushability and occasional kinking of the guide wire during retraction of the balloon with the first generation monorail catheters caused some concern. Both problems have been substantially improved by lengthening of the second distal lumen, which accommodates the guide wire, from $5 \mathrm{~cm}$ to $9-17 \mathrm{~cm}$ (Monorail Snake, $9 \mathrm{~cm}$; Picolino, $17 \mathrm{~cm}$ ).

The risk of thromboembolic complications $(1.4 \%)$ was higher because the guide wire remains in the coronary artery for longer. Full anticoagulation must be maintained (a second or third bolus infusion of heparin may be needed during lengthy procedures) with on line monitoring of anticoagulation.

\section{CONCLUSION}

With the monorail technique it is easier to obtain good angiograms to monitor all important steps of the coronary angioplasty procedure and safe, easy, and rapid recrossing is facilitated. The monorail technique was successful in $90 \%$ of 1000 patients and the rate of major complications (death, myocardial infarction, acute bypass surgery) was $<4 \%$. The transstenotic pressure difference cannot be measured through standard monorail balloon catheters. In future, however, smaller guide wires will be developed to allow measurement of pressure through the monorail catheter.

1 Gruentzig AR, Senning A, Siegenthaler WE. Nonoperative dilatation of coronary artery stenosis-percutaneous transluminal coronary angioplasty. $N$ Engl J Med 1979, 301:61-8

2 Simpson JB, Baim DS, Robert EW, et al. A new catheter system for coronary angioplasty. Am J Cardiol 1982, 49:1216-22.

3 Dervan JP, McKay RG, Baim DS. The use of an exchange guide wire in coronary angioplasty. Cathet Cardiovas Diagn 1985;11:207-12.

4 Kaltenbach $M$. The long guide wire technique-a new technique for steerable balloon catheter dilatation of coronary artery stenoses. Eur Heart J 1984;5:1004-9.

5 Bonzel T, Wollschlaeger $H$, Kasper W, Meinertz T, Just $H$. The sliding rail system (monorail): description of a new technique for intravascular instrumentation and its application to coronary angioplasty. $Z$ Kardiol application to

6 Detre KM, Myler RK, Kelsey SF, Van Raden M, To T, Mitchell $H$. Baseline characteristics of patients in the National Heart, Lung, and Blood Institute Percutaneous Transluminal Coronary Angioplasty Registry. Am J Car diol 1984;53:7C-11C.

7 Kelsey SF, Mullin SM, Detre KM, et al. Effect of investigator experience on percutaneous transluminal coronary angioplasty. Am J Cardiol 1984;53:56C-64C.

8 Meier B, Gruentzig AR. Learning curve for percutaneous transluminal coronary angioplasty: skill, technology or patient selection. Am J Cardiol 1984;53:65C-8C

9 Faxon DP, Kelsey SF, Ryan TJ, McCabe CH, Detre K Determinants of successful percutaneous transluminal Determinants of successful percutaneous transluminal Lung, and Blood Institute Registry. Am Heart J 1984; 108(suppl 1):1019-23.

10 Anderson HV, Roubin GS, Leimgruber PP, Douglas JS Jr, King SB Jr, Gruentzig AR. Primary angiographic success rates of percutaneous transluminal coronary angioplasty. rates of percutaneous translumir

11 Detre K, Holubkov R, Kelsey S, et al. Percutaneous transluminal coronary angioplasty in 1985-1986 and 1977-1981. The National Heart, Lung, and Blood Institute Registry. N Engl J Med 1988;318:265-70.

12 Tuzcu EM, Simpfendorfer C, Badhwar K, et al. Determinants of primary success in elective PTCA for significan narrowing of a single major coronary artery. Am J Cardio 1988;62:873-5.

13 Wijns W, Serruys PW, van den Brand M, et al. Transstenotic pressure gradients obtained during coronary angioplasty are useful but artifactual measurements [Abstract]. Circulation 1984;70(suppl II):11-299.

14 Sigwart U, Grbic M, Goy JJ, Essinger J. High fidelity pressure gradients across coronary artery stenoses before pressure gradients across coronary artery stenoses before
and after transluminal angioplasty [Abstract]. J Am Coll and after transluminal

15 Leimgruber PP, Roubin GS, Hollman J, et al. Restenosis after successful coronary angioplasty in patients with single-vessel disease. Circulation 1986;73:710-7. 